critical faculties of both patients and some members of the profession. If the reader is unconvinced by this attitude, may I remind him of the thalidomide tragedy ? - I am, etc., Oldham, Lancs. P. C. Steptoe.

REFERENCES

I Dodek, O. I., and Kotz, H. L., Amer. F. Obstet. Whyec., 1967 . 98, 1065. . s. Amearman, R. P., Lancet, 1968, 1, 325.

\section{Early Diagnosis of Large Bowel Cancer}

SIR,-Your leading article ( 9 March, p. 592) emphasizes the value of a simple test for blood in faeces in screening for possible causes of gastrointestinal disease including carcinoma. We have recently surveyed 53 patients referred to us with unexplained hypochromic anaemia. Gastrointestinal blood loss was measured with ${ }^{51} \mathrm{Cr}$ tagged red cells ${ }^{1}$ and three consecutive specimens of faeces were tested with the "Hematest" tablet (Ames Company Ltd.). Correlation was good ; 22 gave negative results by both methods. In 27 cases the faeces contained more that $3 \mathrm{ml}$. of blood per 100 g., and all gave positive "Hematest" results within 100 seconds. In four cases the tablet test was doubtful and the specimens contained 1-2 ml. of blood per $100 \mathrm{~g}$. of faeces. We conclude that the "Hematest" tablet is sensitive enough for the detection of most cases of significant bleeding. As no special precautions with diet are necessary, it is ideal for general-practitioner use and should be employed in all cases of hypochromic anaemia. We think that previous views ${ }^{2}$ that the tablets have too low a sensitivity may have prejudiced against their routine use.

Further investigation of the 27 patients with significant bleeding resulted in the following diagnoses:

\begin{tabular}{|c|c|c|}
\hline $\begin{array}{l}\text { Radiologically } \\
\text { Demonstrated }\end{array}$ & & $\begin{array}{c}\text { Not Radiologically } \\
\text { Demonstrated }\end{array}$ \\
\hline 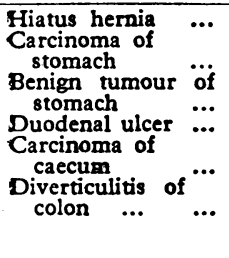 & $\begin{array}{l}1 \\
1\end{array}$ & $\begin{array}{lll}\begin{array}{l}\text { Carcinoma of } \\
\text { jejunum }\end{array} & & \\
\text { Benign ulcer of } & \ldots & 2 \\
\text { ileum } \ldots & \ldots & 1 \\
\begin{array}{l}\text { Intussusception of } \\
\text { ileum }\end{array} & \ldots & 1 \\
\begin{array}{l}\text { Haemangioma of } \\
\text { caecum }\end{array} & \ldots & 1 \\
\begin{array}{l}\text { Carcinoma of } \\
\text { caecum }\end{array} & \ldots & 2 \\
\begin{array}{l}\text { Diverticulum of } \\
\text { caecum }\end{array} & \ldots & 1\end{array}$ \\
\hline
\end{tabular}

In eight patients a diagnosis was not made.

Our results indicate that lesions of the small intestine and caecum are a relatively common cause of hypochromic anaemia, and support the plea that every case demonstrated to be due to gastrointestinal bleeding demands a determined search including exploratory laparotomy. ${ }^{3}-\mathrm{We}$ are, etc.,

$$
\begin{aligned}
& \text { E. J. WATSON WILLIAMS. } \\
& \text { M. C. G. ISRAËLS } \\
& \text { Department of Clinical } \\
& \text { Haematology, } \\
& \text { The Royal Infirmary, } \\
& \text { Manchester 13. }
\end{aligned}
$$

REFERENCES

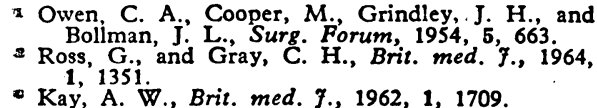

\section{Immunosuppression and Antibiotics}

SIR,-I read with interest your leading article on "South African Heart Transplant " (20 January, p. 132). You referred to the fact that the patient was barriernursed in a special room, and great care was taken against introducing infection, but there was no information as to whether the doctors considered the pathogenicity of the so-called "opportunist" bacteria-E. coli, Proteus, Klebsiella pneumoniae, Pseudomonas aeruginosa-and Pneumocystis carinii and Candida albicans, which can produce even fatal disease in a patient who is on immunosuppressive therapy.

There is no information as to whether they were looking for Gram-negative bacteria in the sputum, in the nasopharyngeal smear, or in blood and faeces. The broad-spectrum antibiotics give a false sense of security, but our experience shows that the $\mathrm{Kl}$. pneumoniae is very often resistant against chloramphenicol and often against streptomycin, neomycin, and polymyxin $B$ also.

Our opinion is that the antibiotic protection of a patient undergoing heart transplantation should be based upon these facts too. The combination of oxacillin, cephaloridin, and polymyxin $B$ has proved to be effective against Gram-negative bacteria; and gentamicin is effective against Pseudomonas aeruginosa. ${ }^{1}-\mathrm{I} a \mathrm{~m}$, etc.,
Postgraduate Medical School,
B. STEINER. Budapest, Hungary.

\section{REFERENCB}

Brit. med. F., 1967, 2, 522

\section{Influenza Virus and Carcinogenesis}

SIR,-Regarding the cancerogenesis from influenza virus in the lungs of mice reported by Drs. R. J. C. Harris and G. Negroni (16 December, p. 637) I should like to report the results of an investigation of my own, in which I exposed mice of the Swiss strain to the inhalation of an aerosol of Myxovirus influenzae $B$ Lee at the dose of $10^{\circ} \mathrm{egg}$ infectious doses (E.I.D.) for 15 minutes. ${ }^{1-3}$

With the electronmicroscope I observed specific damage in the alveolar cells containing lamellar inclusions. In effect, the reproduction of the virus took place at the level of cell membranes (Fig.) as well as in the membranes of the apparatus of Golgi and in those of the lamellar inclusions.

According to current opinion," these lamellar inclusions produce the tensioactive substance responsible for pulmonary elasticity. I submit that the lamellar inclusion damage wrought by the influenza virus could

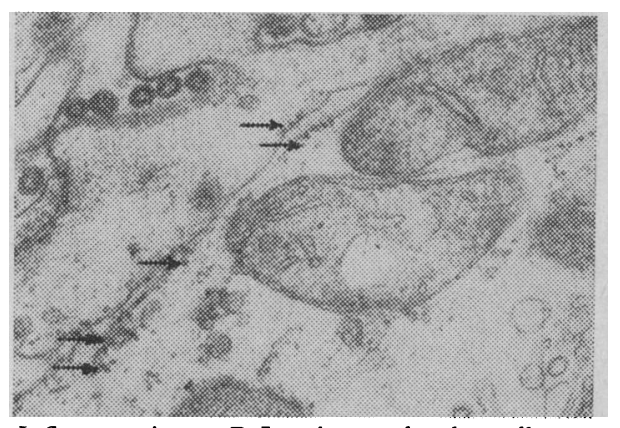

Influenza viruses $B$ Lee in an alveolar cell containing lamellar inclusions. Arrows indicate virus particles. $(\times 35,000$. $)$ result in carcinogenesis through two distinct mechanisms. One is by favouring the stagnation of inhaled carcinogens through reduced alveolar elasticity. (The contact time of carcinogens is often a decisive factor, as exemplified by the high frequency of vesical carcinoma in aniline workers as contrasted with the rarity of tumours of the renal pelvis where the passage of urine is rapid.)

Secondly, the loss of alveolar elasticity and reduced alveolar oxygenation may lead to sclerosis, which in turn may represent a carcinogenic factor. There is currently a tendency to find similarities between tumours from plastic substances and tumours from sclerosis $;^{5}$ the latter may include tumours that develop at the sites of previous burns, frostbite, chronic osteomyelitis, pulmonary tuberculosis, lupus, and the like.-I am, etc.,

Carlo Sirtori.

Department of Pathology, Milan, Italy.

REFERENCES

1 Sirtori, C., in Proceedings of the Third European Regional Conference on Electron Microscopy, edited by $M$. Titlbach, Prague, 1964 , p. 329. Sirtori, C., Gerontologia (Basel), 1964, 9, 239. - Clements, J. A., Hustead, R. F., Johnson, R. P and Gribetz, I., f. appl. Physiol.; 1961, 16, 444. Sirtori, C., Minerva med., 1963, 54, 3686

ryson, G., and Bischoff, F., Progr. exp. Tumour

\section{Deaths from Asthma}

SIR,-In their article on the increase in asthma deaths Dr. F. E. Speizer and others (10 February, p. 339) point out that catecholamines were the drugs used most often immediately before the terminal episode and that isoprenaline, usually in the form of an aerosol spray, was most frequently preferred.

Any drug given in the form of an aerosol would reach the smooth muscle of the bronchi in the full dose very rapidly. If the patient repeated the inhalation sooner than had been recommended he would rapidly receive an overdose. Isoprenaline is a drug which normally has the beta actions of adrenaline. It relaxes the smooth muscle of the arterioles and the bronchi ; and it increases the rate and force of contraction of the heart. However, if it is given in repeated doses at frequent intervals its action changes. It no longer further stimulates the heart; it does not dilate the blood vessels but actually constricts them. ${ }^{2}$ Isoprenaline inhibits the smooth muscle of the uterus, but in the presence of this drug the uterus starts to escape from the inhibition and a second dose of isoprenaline now causes contraction. ${ }^{2}$ The uterus therefore escapes from the effect of isoprenaline, becomes resistant to its inhibitory effect, and the action of the drug is reversed. The uterine contraction induced by isoprenaline in these circumstances is readily antagonized by Hydergine (dihydroergocornine, dihydroergocristine, and dihydroergocryptine). ${ }^{3}$

As reversal of the action of isoprenaline occurs in several different types of smooth muscle, it might also occur in the bronchi. If this is so administration of excess isoprenaline might induce bronchospasm. Endogenous adrenaline is another possible contributory factor. Normally adrenaline relaxes arterioles in skeletal muscles, but this action is reversed by pretreatment with large doses of isoprenaline. ${ }^{1}$ Adrenaline normally relaxes 
the rat uterus, but when given after isoprenaline the action is reversed and the uterus contracts. $^{2}$ It may be supposed that in a severe attack of asthma the patient is alarmed and is secreting adrenaline which would normally relax the bronchioles; if an excess of isoprenaline has been taken the effect of adrenaline will be reversed, leading to bronchoconstriction, and making death more likely. The prolonged use of isoprenaline might therefore defeat its own ends. It is not known what effects corticosteroids have on the action of catecholamines. Research on all these questions is urgently needed.-I am, etc.,

\section{ANNE TOTHILL \\ London Hospital Medical College. London E.1. \\ REFERENCES} Butterworth, K. R., Brit. F. Pharmacol., 1963, 21, : Tothili, Anne, Nature (Lond.), 1967, 213, 1230.
Tothill, Anne, Brit. F. Pharmacol., 1967, 29, 291.

SIR,-Your correspondent Dr. W. H. Helm (9 March, p. 639) writes of " the still widely held belief, especially in children, that asthma is largely a psychologically determined condition," and suggests that " reluctance to use steroids is a likely consequence of this attitude." Sometimes asthma is clearly psychologically determined, and this is a compelling reason for using steroids. One sees people who have had but a few attacks who cough in the night as they contemplate their tax debts or their newly dead mother, and who rapidly acquire the habit of getting extremely breathless. They have normal peak expiratory flow rates between attacks (which cannot be said for most of the people who clutch aerosol canisters). They generally seem to get worse, and some die of asthma ; some seem to stop getting attacks spontaneously. But with steroids they often seem to stop getting attacks, so that one has the feeling that a disease process has been aborted.

It is the early attacks which should be diagnosed accurately and treated vigorously, whether in children or in adults. If the habit of worsening the wheezing is to be avoided, the symptom of breathlessness needs to be relieved quickly. The use of an effective drug early in asthma should be compared to the use of amylobarbitone early in "battle fatigue "-in order to break a pattern before it becomes fixed. Some cases of asthma seem to be preventable.-I am, etc.,

$$
\begin{gathered}
\text { Gravesend, } \\
\text { Kent. }
\end{gathered}
$$

B. Dalton.

\section{Corticosteroids in Asthma}

SIR,-The excellent report by Dr. $K$. Maunsell and others (16 March, p. 661) confirms that steroids can be used as a longterm measure in the management of asthma, and that side-effects are related to the average dose of steroids used, rather than to the length of treatment. No mention is made, however, of whether other bronchodilator agents are used in conjunction with the prednisone. It is my routine practice to give conventional bronchodilator drugs (usually ephedrine or orciprenaline) in a regular oral dosage in addition to the steroids, as I believe this reduces the dose of prednisone required, and so lessens the likelihood of side-effects.
I have recently been using disodium cromoglycate (Intal) for the same purpose, and although the number of patients so far is small I am satisfied that most of them have been able to reduce their dose of prednisone.-I am, etc.,

Chest Clinic,
Cambridge.
M. J. Gremnberg.
Intracardiac E.C.G. in Pacemaker
Electrode Insertion

SIR,-We have found the intracardiac E.C.G. a valuable technique in pacemaker electrode insertion in over 300 routine procedures $^{1}$ when it was used as a supplement to fluoroscopy and in 10 " blind" emergency procedures without fluoroscopy." We present our experience to clarify certain aspects of the paper by Drs. G. Bay and E. Sivertssen (28 October 1967, p. 199).

To assess the position of the electrode tip at all times familiarity with the characteristic intracavitary patterns of S.V.C., I.V.C., pulmonary artery, and coronary sinus ${ }^{3}$ " is needed, as well as the right atrium and right ventricle shown by these authors. The coronary sinus pattern is particularly important, because an initial low pacing threshold usually rises rapidly. $^{s}$ The right ventricular E.C.G. from various areas does not differ sufficiently to position the electrode tip at the apex, which is the optimal site. The contact pattern shown by them needs further elucidation. We have found that if the ST segment elevation is less than $1.5 \mathrm{mV}$ early tip displacement is common. ${ }^{b}$ Also, advancing the electrode further may initially increase ST elevation, but after $0.5-1.0 \mathrm{~cm}$. ST depression supervenes. Withdrawal restores ST elevation. This is interpreted as an intramyocardial E.C.G. and a warning of the risk of complete myocardial perforation. When satisfactory ST elevation is obtained the patient should breathe rapidly and deeply and cough if possible. The ST elevation should not vary under these circumstances.

The electrode which they used was probably of the Elema type. We do not recommend its use in "blind" emergency procedures, especially if an arm vein is chosen for insertion. This very flexible electrode is difficult to pass to the heart from the arm and difficult to manipulate once in the heart, requiring the patient to turn to the left lateral position to facilitate passage of the tip through the tricuspid valve. Use of United States Catheter and Instrument Corporation (U.S.C.I.) electrodes C.50, C.51, and C.52 allows greater control by the operator, avoids rotation of the patient, which may be difficult in an emergency, and speeds the procedure. Five to ten minutes is the customary length of our "blind" procedures. We also use an arm vein, and, although percutaneous subclavian venepuncture ${ }^{7}$ is a faster approach, there is risk of pneumothorax in unskilled hands. We do not use external jugular veins, because they may be difficult to locate in shocked patients and they may later be required for long-term pacing systems. It is important that the threshold obtained is appropriate to the electrode used. For the U.S.C.I. elec trodes we insist on less than 1 volt at 2 milliseconds. We deliver an output voltage of twice threshold, ${ }^{8}$ as the underlying lesion lowers the ventricular fibrillation threshold in many of these patients.
Ventricular fibrillation is a risk of the blind procedure. Our incidence is one in ten cases. Dalle also reported a $10 \%$ incidence. $^{10}$ A D.C. defibrillator must always be immediately available. A series of ventricular ectopics is frequently noticed when the electrode tip traverses the tricuspid valve.-We are, etc.,

K. Chatterjee. RICHARD SUTTON:

\section{Cardiac Department,
St. George's Hospital, St. George's Hosp
London S.W.1.}

\section{REFERENCBS}

1 Harris, A., Redwood, D., and Davies, G., Com munication to Autumn meeting of Britis Chatterjee, K., and Sutton, R., 1968, unpub lished.

Dickerson, R. B., and Caris, T. N., Circulation 1959, 20, 928 .

Emslie-Smith, D., Brit. Heart F., 1955, 17, 219 Davies, G., and Sowton, E., Brit. Heart f., 1966 28, 231.

- Edwards, A., 1965, unpublished. Mogil, R. A., de Laurentis, D. A., and Rose mond, G. P., Arch. Surg., 1967, 95, 320. Meeting of British Cardiac Society. To be pub

- Wished. F. Physiol., 1940, 131, 309.

Dalle, X., Proceedings of Conference on Cardias
Pacing and Cardioversion, 1967. Philadelphis.

\section{Dental Anaesthesia}

SIR,-The Ministry of Health's report ${ }^{1}$ on dental anaesthesia has the seal of authority. It has been widely circulated and publicized; referred to in coroners' courts and in the national press ; and now in your editorial comment (24 February, p. 462) it is given an additional boost. Before being finally accepted as gospel it should be looked at critically.

According to the argument put forward in the report, dental anaesthesia has never been so dangerous, and yet the facts show that dental anaesthesia has never been so safe. In 1952 there were $2 \frac{1}{2}$ million administrations in England and Wales." Now there are 2 million a year (report, page 19). But the mortality has fallen dramatically. In the period 1952-56 deaths were running at 17 a year (page 9). Now there are six a year (page 24, Table 3). And of these six four are occurring in dental patients anaesthetized in hospitals (i.e., by anaesthetists) and only two in dentists' surgeries, where, according to the report, all but a small proportion of the two million administrations are given - and this surprisingly low mortality in dentists' surgeries despite the fact that over a million of the administrations are given by dentists, and over 400,000 of these by the dentists performing the operation (page 28, Appendix D).

But there is another reason for regarding. the report as biased. A year before it was published, and while its authors were still collecting evidence, I published ${ }^{3}$ evidence showing that it really made little difference what anaesthetic was used in dentistry or who gave it. Unaccountable deaths in young, healthy patients occurred with doctors and even with specialist anaesthetists. By far the greatest danger was the traditional upright position of the patient, which was directly responsible for nearly all the deaths and morbidity ; and the remedy was to abandon this position. I sent a copy of my communication to the authors of the report. The 